УДК 347.97

DOI https://doi.org/10.32849/2663-5313/2020.3.54

\title{
Богдан Деревянко,
}

докт. юрид. наук, професор,

провідний науковий співробітник відділу міжнародного приватного права

і порівняльного правознавства

Науково-дослідного інституту приватного права і підприємництва

імені академіка Ф. Г. Бурчака Національної академії правових наук України,

професор кафедри господарсько-правових дисииллін

Донещького юридичного інституту Міністерства внутрішніх справ Украйни

\section{ЩОДО ФОРМУВАННЯ ТА ДІЯЛЬНОСТІ СПЕЦІАЛІЗОВАНОГО ІНВЕСТИЦІЙНОГО СУДУ УКРАЇНИ}

Україна съогодні як ніколи потребує іноземних інвестицій. Проте довіра інвесторів до української судової системи підірвана. Можливо, через ие Президент України пообіияв іноземним інвесторам застосування принципово нового судового захисту їхніх інтересів. Відновити довіру іноземного інвестора, а в перспективі й українського, до судової системи можливо двома шляхами - покращенням роботи МКАС при ТПП України або утворенням нового судового органу - Вищого інвестиційного суду України. У разі утворення такого органу потрібно буде зменшити обсяг юрисдикиії діючих загальних та спечіалізованих судів, а також кількість посад суддів та обслуговуючого персоналу. Ціль статті полягала у визначенні ступеня необхідності утворення нового спещіалізованого суду із захисту прав іноземних інвесторів та формування основних складників його діяльності. 3 урахуванням потреби у додаткових витратах Державного бюджету та певній ефективності роботи МКАС при ТПП України було зроблено висновок, що ступінь необхідності є середнім. Підвищення ефективності роботи МКАС при ТПП України та інших загальних і спещіалізованих судів із захисту інтересів інвесторів може зробити непотрібною ідею створення нового суду. Проте ефективність роботи такого суду в частині захисту інтересів іноземних інвесторів була б найвищою за умови подання ними позовів на суми до 10000 доларів США та незамінною за умови подання позовів на суми до 1800 доларів США.

Зроблено висновок, що ефективність роботи нового - Вищого інвестиційного - суду України складатиметься із соиіальної та економічної частин, а саме: його утворення буде виправдано за умови пропориійного зменшення посад суддів та обслуговуючого персоналу в інших загальних та спеиіалізованих судах, відновлення довіри іноземних інвесторів через швидкий та справедливий розгляд спорів, відсутності корупиійних підозр стосовно суддів та інших співробітників нового судового органу.

Ключові слова: Вищий інвестиційний суд України, МКАС при ТПП України, Верховний суд України, іноземні інвестори, судова система, юрисдикція.

Постановка проблеми. Значення інвестицій для будь-якої держави неможливо переоцінити. Економіку країни без внутрішніх і зовнішніх фінансових вливань в інновації, технології та виробництво неминуче чекає колапс у вигляді нескінченних дефолтів, гіперінфляцій, відтоку інтелектуальних та трудових ресурсів тощо. Можемо згадати приклад прадавнього Китаю, економіка якого значно випереджала економіку усіх тогочасних держав та внаслідок самоізоляції, зокрема і фізичної через будівництво стіни, втратила свої позиції та дозволила агресивним сусідам захопити більшу частку теритоpiї держави.

Інвестиції в українську економіку є у кілька разів меншими, ніж в економіки більшості сусідніх держав. Причин, що викликали такий стан, досить багато. Сьогодні не варто їх вишукувати, а потрібно створювати умови, що сприятимуть захисту інвестицій, підвищенню ïx кількісних та якісних показників. Такі умови можуть реалізовуватися через надання та дотримання державою гарантій захисту внутрішніх та іноземних інвестицій. Серед таких гарантій іноземних інвесторів цікавить наявність права на дійсно чесний і неупереджений професійний судовий розгляд усіх суперечливих моментів і непорозумінь між ними, реципієнтами та державою Україна.

Протягом останніх років через різні причини державі вдалося частково поліпшити результати у боротьбі з корупцією, зокрема, у сферах освіти, медицини, надання державних послуг тощо. Проте частина заслуги належить не удосконаленим нормам права, 
а сучасним пристроям звуко- та відеозапису, комп'ютерним технологіям тощо, що виступають заходами стримування порушників. Загалом, іноземці досі не довіряють українській судовій системі. I це було однією із причин пропозиції Президента України, висловленої 23 січня 2020 року у Давосі, щодо утворення в Україні окремого суду (арбітражу) для інвесторів.

Аналіз останніх досліджень і публікацій. Питанням організації діяльності судової системи України, загальних та галузевих судів, виконанню судових рішень приділяли увагу вітчизняні юристи, зокрема О. М. Беляневич [1], А. А. Бутирський [2], О. П. Віхров [3], С. М. Грудницька [4], С. Ф. Демченко [5; 4; 6; 7], В. В. Джунь [8], В. О. Коверзнев [3; 9], Л. М. Ніколенко [10; 11; 12], О. П. Подцерковний [13; 14; 15], Б. М. Поляков [16], В. В. Рєзнікова [17; 18; 19; 20], М. Л. Шелухін [21], В. С. Щербина [19; 20] та інші. У попередніх роботах нами висловлювалися думки на користь захисту системи господарських судів в Україні [22] та щодо пошуку напрямів підвищення ефективності виконання рішень господарських та інших судів [23; 24]. Проте у роботах названих авторів не йшлося про захист інтересів іноземних чи українських інвесторів у новому окремому спеціалізованому суді.

Мета статті - визначення ступеня необхідності утворення нового спеціалізованого суду із захисту прав іноземних інвесторів та формування основних складників його діяльності.

Виклад основного матеріалу. Питання стосовно необхідності утворення нового судового органу є дискусійним та суперечливим, проте не позбавленим сенсу. Так, одним із позитивів розгляду спорів у новому «інвестиційному» суді для іноземного інвестора-позивача буде відносно невисока сума судового збору. Арбітражний збір у Міжнародному комерційному арбітражному суді при Торгово-промисловій палаті України (далі - МКАС при ТПП України) є досить високим (якщо вартість позиву - до 10000 доларів США, сума арбітражного збору становить 1800 доларів, а спір на суму, меншу за 1800 доларів США, взагалі позбавлений економічного сенсу). Тобто Україна може втрачати інтерес невеликих іноземних інвесторів через неефективність захисту своїх незначних капіталів, які могли б стати умовними першими або пробними частками чи траншами. Без цього, можливо, інвестор не ризикне робити серйозні вливання в українську економіку. До речі, досвід багатьох ЗВО чи наукових установ свідчить, що часто уже за другою грантовою програмою від іноземного фонду чи держави сума $є$ у сотні разів більшою, ніж за першою. На нашу думку, сьогодні Україні потрібен новий судовий орган, покликаний захищати права інвесторів - внутрішніх та насамперед іноземних.

Якщо вважати щойно надану відповідь на питання «чи потрібен такий суд?» однозначною, то слід поміркувати та надати відповідь на декілька наступних, не менш важливих питань. Головним із них буде питання стосовно економічної доцільності утворення нового державного судового органу, який потребує певного фінансування із і без того дефіцитного Державного бюджету. Також потрібно визначитися із назвою та підпорядкуванням такого судового органу, місцем його розташування, кількісним та якісним складом суддів та обслуговуючого персоналу, джерелами та обсягами фінансування, юрисдикцією і підсудністю та ін.

Викладене нижче матиме дискусійний характер, оскільки буде висловлено вперше, а також передбачатиме значну варіативність у засобах і способах реалізації. Отже, якщо вважати доцільним утворення нового судового органу, то логічним буде надати йому назву - Вищий інвестиційний суд України у складі Верховного суду України. У цьому разі після розробки та прийняття (ухвалення, затвердження) відповідної нормативної бази (легітимації діяльності такого суду) можна схематично представити структуру Верховного суду України:

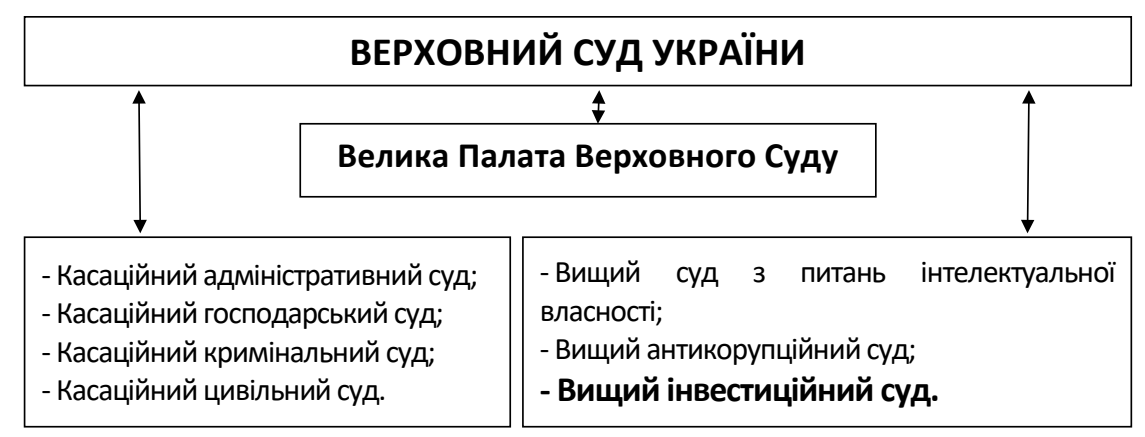




\section{$3 / 2020$ \\ судоУстРІй}

Як видно зі схеми, нами пропонується утворити новий судовий орган у складі Верховного суду України. Він має отримати статус, схожий зі статусом Вищого антикорупційного суду та Вищого суду з питань інтелектуальної власності. Фізичне місце знаходження (розміщення) нового судового органу буде тісно пов'язане з його кількісним складом. Відповідно, кількісний склад повинен бути пропорційним кількості спорів, які розглядатимуться суддями. А ця кількість залежатиме від юрисдикції та територіальної юрисдикції (підсудності) [25].

До юрисдикції Вищого інвестиційного суду України логічно віднести здійснення правосуддя як суду першої та апеляційної інстанцій у справах щодо захисту прав і законних інтересів зарубіжних інвесторів, а також здійснення у випадках та порядку, визначених законодавством про захист іноземних інвестицій, судового контролю за дотриманням прав, свобод та інтересів осіб у відповідних провадженнях. Утворення нового суду у складі двох інстанцій пов'язане з необхідністю повного дотримання інтересів учасників судового розгляду, зокрема і дотримання права на апеляційне оскарження. Підсудність (територіальна юрисдикція) має поширюватися на територію усієї України.

Завдання щодо розміщення (місця знаходження) нового суду можна вирішити за аналогією 3 нормами статті 15 «Вимоги до розміщення Вищого антикорупційного суду» Закону України «Про Вищий антикорупційний суд». Можна запропонувати статтю, яку буде включено або до нового спеціального закону, або до Закону України «Про судоустрій і статус суддів»:

«Стаття. Вимоги до розміщення Вищого інвестиційного суду

1. Апеляційна палата Вищого інвестиційного суду та судові палати Вищого інвестиційного суду для здійснення правосуддя в першій інстанції не можуть розміщуватися в одній будівлі.

2. Вищий інвестиційний суд, його палати та апарат не можуть розміщуватися в одній будівлі разом з іншими судами, державними органами, їх територіальними, структурними підрозділами, представництвами, органами місцевого самоврядування, установами, організаціями».

Безпосереднє місце розташування двох палат Вищого інвестиційного суду України має визначатися у порядку, за яким це робилося під час визначення розташування двох палат Вищого антикорупційного суду України. Але, враховуючи ранг та статус нового суду, таке місце має бути у столиці держави - місті Києві. При цьому у разі формування нового суду невеликою кількістю суддів (як палати для здійснення правосуддя в першій інстанції, так і апеляційної палати), можливо, їм вистачить і частини певних будівель, проте $з$ окремим входом або з окремою від інших частиною будівлі (окремим крилом чи прибудовою). Останнє дозволить організувати ефективну охорону та пропускний режим.

Питання щодо кількісного та якісного складу Вищого інвестиційного суду можна вирішити двома шляхами.

Перший має спиратися на аналіз судової практики та статистики діяльності судів загальної юрисдикції, господарських судів, Вищого суду з питань інтелектуальної власності. Слід визначити середню кількість спорів, пов'язаних із захистом прав іноземних інвесторів, що розглядалися у цих судах протягом останніх років. На основі цього показника та показника середньорічного навантаження на одного суддю можна визначити потрібну кількість суддів.

Другий шлях: можна призначити мінімально необхідну кількість суддів у кожну із двох палат нового Вищого інвестиційного суду, що буде пропорційною можливостям державного фінансування. А вже після початку роботи суду за підсумками піврічного чи річного строку його діяльності кількісний склад нового суду може бути відкоригований.

Фінансове забезпечення нового суду має здійснюватися з Державного бюджету України.

Судді до Вищого інвестиційного суду мають набиратися на основі конкурсу, аналогічного тому, за яким здійснювався набір до Вищого антикорупційного суду України. 3 іншого боку, після зміни юрисдикції діючих господарських, загальних судів та/або Вищого суду з питань інтелектуальної власності і, відповідно, зменшення навантаження на ці суди, можна буде відкоригувати їх кількісний склад шляхом зменшення кількості посад суддів та обслуговуючого персоналу. Ця кількість в ідеалі має дорівнювати кількості суддів та обслуговуючого персоналу новоутвореного Вищого інвестиційного суду. Іншими словами, слід провести рокіровку між наявними та новим судом. У такому разі не буде збільшено витрати Державного бюджету на заробітну плату та нарахування на неї. Проте державні витрати все одно зростуть через потребу утримання двох нових приміщень (їх частин) у місті Києві.

Збільшення навантаження на Державний бюджет України є однією із причин, що викликали спротив ідеї створення нового судового органу у багатьох вчених 
та практиків. Так, під час обговорення такої ідеї у межах НДІ приватного права і підприємництва ім. акад. Ф.Г. Бурчака НАПрН України завідувач відділу міжнародного приватного права та порівняльного правознавства В .І. Король, суддя Верховного Суду К. М. Пільков та арбітр МКАС при ТПП України В. І. Нагнибіда стали на позицію захисту інтересів іноземних інвесторів у межах уже наявних у світі міжнародних інвестиційних арбітражів та МКАС при ТПП України [25]. У такій позиції є раціональне зерно, яке полягає, зокрема, у призначенні у більшості випадків двох із трьох суддів самими сторонами. Також державі не потрібно робити додаткові фінансові витрати та змінювати законодавство. Слід лише отримати та підтримувати на максимальному рівні довіру іноземних (та й українських) інвесторів до арбітражу і системи діючих господарських судів.

Якщо ж іти шляхом утворення нового суду, то під час розробки нормативної бази, якою буде визначено правовий статус Вищого інвестиційного суду та його суддів (нового закону чи доповнень до Закону України «Про судоустрій і статус суддів»), слід буде вносити зміни до норм, якими визначається юрисдикція судів загальної юрисдикції та спеціалізованих судів, а також інших кодексів і загальних та спеціальних законів України. Також потрібно звернутися до позитивного досвіду діяльності МКАС при ТПП України, а також правового регулювання такої діяльності; правового режиму діяльності відповідних судів у європейських державах та інших державах-фінансових лідерах світу (США, КНР, Японії, Південної Кореї та ін.).

На перших етапах роботи нового суду до складу його юрисдикції логічно було б віднести захист прав іноземних інвесторів, а за підсумками роботи суду за рік чи за більший строк можна буде провести дискусію та науковий аналіз на предмет уможливлення поширення юрисдикції цього суду на спори із захисту прав внутрішніх інвесторів.

\section{Висновки}

На основі розглянутого у статті, потрібно вказати на наявність двох підходів до підвищення ефективності захисту прав іноземних інвесторів українською судовою системою. Перший полягає у продовженні забезпечення такого захисту МКАС при ТПП України, загальними та спеціалізованими (зокрема, господарськими) судами. Розгляд спорів у МКАС при ТПП України робить економічно недоцільним для інвестора захист невеликих інвестицій. На перше місце за першого підходу має виходити підвищення рівня довіри інвесторів до судів. Другий підхід полягає в утворенні нового судового органу - Вищого інвестиційного суду України.
Виходячи із наявності та досить ефективної діяльності МКАС при ТПП України, ступінь необхідності утворення нового спеціалізованого суду із захисту прав іноземних інвесторів $€$ не найвищим, а скоріше середнім. Проте насамперед новий судовий орган був би ефективним у разі розгляду спорів із ціною позову до 10000 доларів США та незамінним при такій ціні до 1800 доларів США. Утворення нового - Вищого інвестиційного - суду України буде ефективним за умови зміни юрисдикції i, відповідно, зменшення кількості посад суддів та обслуговуючого персоналу в інших загальних та спеціалізованих судах, а також швидкого і справедливого розгляду спорів за відсутності будь-яких корупційних підозр принаймні у перші роки його діяльності. Тільки з дотриманням цих умов може бути отримано довіру іноземних інвесторів і доведено суспільну та економічну ефективність утворення і роботи нового судового органу України.

Подальші наукові розвідки незалежно від того, чи буде утворено Вищий інвестиційний суд України, повинні бути присвячені пошуку напрямів подолання організаційних та юрисдикційних проблем у діяльності (потенційній діяльності) нового судового органу (зокрема, щодо надання відповіді про розширення суб'єктної юрисдикції за рахунок українських інвесторів; визначення можливостей зниження витрат на його утримання тощо).

\section{Список використаних джерел:}

1. Беляневич О. Про особливості застосування норм про позовну давність у справах про банкрутство. Підприємництво, господарство право. 2017. № 10. С. 5-9.

2. Бутирський А.А. Реалізація принципу спеціалізації в судовій системі України. Вісник господарського судочинства. 2012. № 6. С. 195-200.

3. Віхров О.П., Коверзнев В.О. До питання про критерії розмежування господарської та адміністративної юрисдикцій. Вісник господарського судочинства. 2011. № 2. С. 110-117.

4. Демченко С.Ф., Грудницька С.М. Нове корпоративне законодавство і проблеми його застосування судами. Економіка та право. 2010. № 1 . С. $52-56$

5. Демченко С.Ф. Теоретико-методологічні засади ефективності господарського судочинства : автореф. дис. ... д-ра юрид. наук : 12.00.04. Київ, 2010. 36 с.

6. Демченко С.Ф. Паралелі та меридіани господарських та адміністративних судів. Вісник господарського судочинства. 2009. № 6. С. 73-80.

7. Демченко С. Реформування судової системи: окремі ключові поняття. Юридична Украӥна. 2010. № 10. C. 11-15.

8. Джунь В.В. Теоретико-прикладні проблеми реформування законодавства України про банкрутство : автореф. дис. ... докт. юрид. наук : 12.00.04. Київ, 2009. 30 с. 
9. Коверзнев В.О. Розмежування юрисдикції адміністративних і господарських судів України: проблеми теорії та практики Форум права. 2013 № 2. C. 223-229. URL: http://nbuv.gov.ua/UJRN/ FP index (дата звернення: 11.02.2020).

10. Ніколенко Л.М. Доказування в господарському судочинстві : автореф. дис. ... канд. юрид. наук: 12.00.04. Донецьк, 2004. 17 с.

11. Ніколенко Л.М. Визначення сутності інституту підвідомчості. Вісник Маріупольського державного університету. Серія «Право». 2011. Випуск 1. С. 79-85.

12. Ніколенко Л.М. Господарське процесуальне право України : підручник. Одеса: Фенікс $2011.512 \mathrm{c}$

13. Господарське процесуальне право / О.П. Подцерковний, О.О. Квасніцька, Т.В. Степанова та ін. ; за ред. О.П. Подцерковного, М.Ю. Картузова. Харків : Одіссей, 2011. 400 с.

14. Подцерковний О. Про суперечність європейським стандартам пропозицій щодо ліквідації господарських судів. Юридичний вісник. 2014. № 6 . C. $125-130$.

15. Подцерковний О.П. Досвід спеціалізації господарської (комерційної) юрисдикції в Україні та західних країнах. Вісник Національної академії правових наук України. 2018. Том 25. № 1. С. 146-161.

16. Поляков Б.М. Коментар судової практики Верховного суду України у справах про банкрутство. Київ : Логос, 2008. 488 с.

17. Рєзнікова В.В. Звуження кола справ, підвідомчих господарським судам України : проблема надумана чи реальна ? Науковий вісник Ужгородського національного університету. Серія «Право». 2013. Випуск 22. Частина 2. С. 59-75.

18. Рєзнікова В. Підвідомчість справ господарським судам України: проблеми теорії та прак-

тики. Вісник Київського начіонального університету імені Тараса Шевченка. Правові науки. 2014. № 1(99). C. 24-32.

19. Щербина В., Рєзнікова В. Сучасні тенденції розвитку господарського процесу України. Право Украӥни. 2017. № 9. С. 9-27.

20. Шербина В., Рєзнікова В. Основні засади (принципи) господарського судочинства України. Право Украӥни. 2018. № 7. С. 13-33.

21. Шелухін М.Л., Зубатенко О.М. Господарське процесуальне право. Київ : ЦНЛ, 2006. 264 с.

22. Деревянко Б.В. Важливість функціонування усталеної оптимальної системи господарських судів в Україні. 10 років застосування Господарського кодексу України: сучасний стан та перспективи вдосконалення кодифікаціі : зб. доповідей наук.-практ. конф. (14 листоп. 2014 р., м. Київ) / голова ред. кол. О.П. Подцерковний. Одеса: Юридична література, 2014. С. 345-349.

23. Деревянко Б. Становлення законодавства і практики діяльності органів із забезпечення виконання рішень господарських та інших судів у 1990-2005 роках. Актуальні питання держави $i$ права. 2014. Вип. 73. С. 229-235.

24. Деревянко Б.В. Періодизація правового регулювання виконання рішень господарських та інших судів. Університетські наукові записки. 2014. № 2 (50). С. 192-199.

25. Крупчан О.Д. Концептуально-правові підходи до створення міжнародного інвестиційного арбітражу в Україні. Судебно-юридическая газета. 2020. 10 февраля. URL: https:// sud.ua/ru/news/blog/160775-kontseptualnopravovi-pidkhodi-do-stvorennya-mizhnarodnogoinvestitsiynogo-arbitrazhu-v-ukrayini (дата звернення: 01.02.2020)

Ukraine needs foreign investment today more than ever. However, confidence of investors in the Ukrainian judicial system has been undermined. Perhaps it was the reason why the President of Ukraine promised foreign investors a fundamentally new judicial protection of their interests. It is possible to restore the confidence of a foreign investor, and in the future the Ukrainian one, in the judicial system in two ways: by improving the work of the International Commercial Arbitration Court at the Ukrainian Chamber of Commerce and Industry or by creating a new judicial body - the High Investment Court of Ukraine. If such a body is formed, it will be necessary to reduce the scope of jurisdiction of the existing general and specialized courts, as well as the number of posts of judges and service personnel. The purpose of the article was to determine the need for the formation of a new specialized court for the protection of the rights of foreign investors and the formation of its main components. Taking into account the need for additional expenditures from the state budget and the certain efficiency of the International Commercial Arbitration Court at the Ukrainian Chamber of Commerce and Industry, it was concluded that the degree of necessity is moderate. Increase in the efficiency of the International Commercial Arbitration Court at the Ukrainian Chamber of Commerce and Industry and other general and specialized courts that protect the interests of investors may make the idea of creating a new court unnecessary. However, the efficiency of such a court in protecting the interests of foreign investors would be the highest when they filed claims in the amount of up to 10,000 US dollars and indispensable in filing claims in the amount of up to 1,800 US dollars.

It is concluded that the efficiency of the new High Investment Court of Ukraine will consist of social and economic parts. They will justify its formation, provided the proportional reduction of the posts of judges and staff in other general and specialized courts, restoration of confidence of foreign investors through prompt and fair consideration of disputes, absence of corruption suspicions against judges and other employees of the new judicial body.

Key words: High Investment Court of Ukraine, International Commercial Arbitration Court at the Ukrainian Chamber of Commerce and Industry, Supreme Court of Ukraine, foreign investors, judiciary, jurisdiction. 